KINERJA Jurnal Ekonomi dan Bisnis

Vol. 4 No. 1 - Desember 2021

\title{
PENERAPAN MARKETING MIX PADA PERGURUAN TINGGI
}

\author{
Kurnia Budhy Scorita1, Febbie Handayani² \\ Fakultas Ekonomi dan Bisnis Universitas Islam As-Syafi'iyah ${ }^{1,2}$ \\ kurnia.feb@uia.ac.id1
}

\begin{abstract}
Abstrak
Perbandingan jumlah perguruan tinggi swasta lebih banyak jika dibandingkan dengan perguruan tinggi non swasta atau negeri, tentunya keberadaan sejumlah perguruan tinggi swasta yang sangat banyak, menjadi penyebab munculnya kompetisi hebat diantara perguruan tinggi swasta yang berlomba-lomba membentuk citra yang baik terhadap lembaga dalam upaya menarik perhatian masyarakat terutama menarik minat calon mahasiswa dengan demikian perguruan tinggi swasta dapat mengembangkan berbagai upaya berdasarkan pada konsep pemasaran terutama marketing mix dengan pendekatan delapan indicator product, price, promotion, place, people, process, physical evidence, customer service. Tujuan penelitian ini untuk mengetahui penerapan marketing mix pada perguruan tinggi. Penelitian ini menggunakan pendekatan penelitian kualitatif dengan metode penelitian berdasarakan deskriptif literatur review dari teori marketing mix produk jasa dengan pendekatan pada delapan indikator diantaranya pengelolaan product, price, promotion, place, people, process, physical evidence, customer service dan berdasarkan beberapa hasil penelitian terkait dengan penerapan marketing mix pada perguruan tinggi. Adapun hasil penelelitian menunjukan bahwa ada delapan indikator dalam marketing mix yang efektif diterapkan pada perguruan tinggi diantaranya pengelolaan product, price, promotion, place, people, process, physical evidence, customer service dan diluar indikator tersebut sebaiknya perguruan tinggi menerapkan usaha-usaha selain marketing mix yang sifatnya konstan, terus menerus misalnya pelatihan, seminar dan open house.
\end{abstract}

\section{Kata Kunci : Jasa Pendidikan, Pemasaran Jasa, Marketing Mix}

\begin{abstract}
Tthe number of private universities is more than public universities, of course the existence of a number of private universities is very much the cause of the emergence of great competition among private universities that are competing to form a good image of the institution in an effort to attract public attention, especially attracting interest. prospective students thus private universities can develop various efforts based on marketing concepts, especially the marketing mix with the approach of eight indicators of product, price, promotion, place, people, process, physical evidence, customer service. This study uses a qualitative research approach with research methods based on descriptive literature review of the theory of marketing mix service products with an approach to eight indicators including product management, price, promotion, place, people, process, physical evidence, customer service and based on several research results related to application of the marketing mix in universities. The results of the study show that there are eight indicators in the marketing mix that are effectively applied to universities, including the management of product, price, promotion, place, people, process, physical evidence, customer service and outside of these indicators, universities should implement efforts other than the marketing mix. which are constant, continuous, for example training, seminars and open house.
\end{abstract}

\section{Keywords: Education Services, Service Marketing, Marketing Mix}




\section{PENDAHULUAN}

\section{Latar Belakang Penelitian}

Perkembangan pendidikan tinggi di Indonesia erat kaitannya dengan banyak berdirinya perguruan tinggi swasta yang dari sisi jumlah pun lebih banyak dibandingkan jumlah perguruan tinggi negeri. Keberadaan sejumlah perguruan tinggi swasta yang sangat banyak dapat menciptakan kompetisi dalam mencari para calon mahasiswa baru. sebuah perguruan tinggi harus memiliki sebuah strategi yang tidak hanya dari segi inovasi namun juga dari segi diferensiasi untuk mencari calon mahasiswa baru .(Rahman, 2021).

Berdasarkan statistik pendidikan tinggi yang di terbitkan oleh Kementerian Riset, Teknologi dan Perguruan Tinggi Tahun 2019 menyampaikan bahwa total perguruan tinggi di Indonesia mencapai 4.621. Hal ini dapat dilihat pada Tabel 1 berikut.

\section{Tabel 1}

\section{Perguruan Tinggi di Indonesia}

\section{Tahun 2019}

\begin{tabular}{lccc}
\hline & Nasional & Negeri & Swasta \\
\hline Universitas & 633 & 63 & 552 \\
\hline Institute & 238 & 12 & 102 \\
\hline Sekolah Tinggi & 2.501 & - & 1.424 \\
\hline Akademi & 909 & - & 851 \\
\hline Akademi Komunitas & 36 & 4 & 30 \\
\hline Politeknik & 304 & 43 & 170 \\
\hline Total & $\mathbf{4 . 6 2 1}$ & $\mathbf{1 2 2}$ & $\mathbf{3 . 1 2 9}$ \\
$\quad$ Sumber : https://pddikti.kemdikbud.go.id/ & &
\end{tabular}

Berdasarakan Tabel 1 menunjukan bahwa perguruan tinggi di Indonesia berjumlah 4.621 yang terbagi pada milik negeri dan swasta serta terbagi pada jenjang universitas, institute, sekolah tinggi, akademi, akademi komunitas, dan politeknik. Jika dilihat dari tabel tersebut menunjukan bahwa jumlah perguruan tinggi swasta lebih banyak dibanding dengan perguruan tinggi negeri. Perguruan tinggi di Indonesia tersebar di seluruh provinsi sebagai berikut:

Tabel 2

Jumlah Perguruan Tinggi di Seluruh Provinsi Indonesia Tahun 2019

\begin{tabular}{lc}
\hline Provinsi & Perguruan Tinggi \\
\hline D.K.I. Jakarta & 401 \\
\hline Jawa Barat & 600 \\
\hline Banten & 163 \\
\hline Jawa Tengah & 367 \\
\hline D.I. Yogyakarta & 138 \\
\hline Jawa Timur & 556 \\
\hline Aceh & 158 \\
\hline Sumatera Utara & 343 \\
\hline Sumatera Barat & 136 \\
\hline Riau & 111 \\
\hline Provinsi & 64 \\
\hline Kepulauan Riau & 60 \\
\hline Jambi & 141 \\
\hline Sumatera Selatan & 21 \\
\hline Bangka Belitung & Perguruan Tinggi \\
\hline
\end{tabular}


KINERJA Jurnal Ekonomi dan Bisnis

Vol. 4 No. 1 - Desember 2021

\begin{tabular}{lc}
\hline Bengkulu & 27 \\
\hline Lampung & 125 \\
\hline Kalimantan Barat & 80 \\
\hline Kalimantan Tengah & 39 \\
\hline Kalimantan Selatan & 69 \\
\hline Kalimantan Timur & 80 \\
\hline Kalimantan Utara & 11 \\
\hline Sulawesi Utara & 93 \\
\hline Gorontalo & 17 \\
\hline Sulawesi Tengah & 52 \\
\hline Sulawesi Selatan & 261 \\
\hline Sulawesi Barat & 29 \\
\hline Sulawesi Tenggara & 56 \\
\hline Maluku & 43 \\
\hline Maluku Utara & 26 \\
\hline Bali & 77 \\
\hline Nusa Tenggara Barat & 88 \\
\hline Nusa Tenggara Timur & 75 \\
\hline Papua & 78 \\
\hline Papua Barat & 36 \\
\hline Indonesia & 4.621 \\
\hline Sumber : &
\end{tabular}

Sumber : https://pddikti.kemdikbud.go.id/

Berdasarkan Tabel 2 diatas menunjukan bahwa Jawa barat sebagai provinsi yang memiliki perguruan tinggi terbanyak di Indonesia, tentunya hal ini menunjukan Jawa Barat sebagai provinsi edukasi di Indonesia, dan hal ini pula menunjukan bahwa persaingan perguruan tinggi di Jawa Barat sangat tinggi.

Produk Perguruan Tinggi berupa bidang studi dan ilmu merupakan jasa yang akan ditawarkan kepada konsumen, atau mahasiswa. Perguruan Tinggi memiliki kewajiban dalam melaksanakan pendidikan, melakukan penelitian dan melakukan pengabdian masyarakat, hal ini disebut dengan tri dharma perguruan tinggi. Ketiga jasa tersebut dapat diklasifikasikan sebagai pelayanan jasa yang berulang dan berdaya tahan lama. Dalam membentuk citra yang baik terhadap lembaga dalam rangka menarik minat mahasiswa maka lembaga pendidikan dalam hal ini Perguruan Tinggi Swasta dapat mengembangkan berbagai upaya berdasarkan pada konsep pemasaran, disamping fungsi utamanya sebagai lembaga pendidikan. Dengan tujuan agar konsumen atau mahasiswa mau melakukan pembelian terhadap jasa yang ditawarkan, maka mutu pendidikan harus memuaskan sesuai dengan kebutuhan.(Maspufah, 2020).

Jumlah Perguruan Tinggi Swasta yang cukup tinggi menciptakan terjadinya persaingan antar perguruan tinggi swasta dalam mecari calon pelanggan atau calon mahasiswa. (Risdwiyanto \& Kurniyati, 2015). Sebuah perguruan tinggi juga tidak terlepas dari sistem pemasaran tepatnya bauran pemasaran. Bauran pemasaran pendidikan merupakan unsur penting sehingga hasilnya sebuah strategi pemasaran yang mencapai keunggulan dalam bersaing (Hidayati, 2021)

Hal ini tentunya persaingan perguruan tinggi swasta di Jawa Barat berlombalomba menarik perhatian calon mahasiswa baru. sebuah perguruan tinggi perlu melakukan usaha-usaha pemasaran dan salah satu alat pemasaran yang digunakan untuk mempengaruhi keputusan membeli adalah bauran pemasaran atau dikenal sebagai marketing mix, dimana untuk bidang jasa terdiri dari 7P yaitu product, price, place, promotion, people, process dan physical evidence.(Sudhana, Lukmandono, \& Prabowo, 2019). Hal ini karena pelanggan yang memiliki loyalitas, jika seorang pelanggan tidak 
memperoleh kepuasan maka pelanggan tersebut cenderung bertindak negatif. Sebaliknya jika merasa puas maka pelanggan tersebut akan loyal terhadap perusahaan. (Subagiyo \& Adlan, 2017). Berdasarkan pemaparan tersebut maka peneliti mengkaji marketing mix pada perguruan tinggi, hal ini dilakukan untuk menciptakan keunggulan kompetitif bagi perguruan tinggi di Indonesia.

\section{TINJAUAN PUSTAKA \\ Jasa Pendidikan}

Alma \& Hurriyati dalam (Hidayati, 2021) layanan dalam Lembaga pendidikan merupakan hal yang harus diperhatikan. Sebuah layanan dalam pendidikan diantaranya bangunan fisik, layanan mahasiswa, fasilitas penunjang perkuliahan. Semua konsumen akan mengharapkan sebuah layanan jasa yang memuaskan.

\section{Marketing Mix}

Menurut Tjiptono (2014) dalam (Maspufah, 2020) Bauran pemasaran jasa terdiri dari delapan variabel yaitu:

1. Produk (Product)

Produk jasa memiliki empat karakteristik diantaranya, intangibility (tidak terlihat), tidak tahan lama (perishability), tidak dapat terpisahkan dan dapat berubah setiap saat (variability). (Maspufah, 2020)

2. Harga (Price).

Harga merupakan sebuah biaya yang harus dikeluarkan untuk mendapatkan sebuah produk dan sebaiknya harga produk yang ditawarkan terjangkau oleh konsumen. (Maspufah, 2020)

Penetapan sebuah harga sebaiknya disesuaikan dengan kualitas produk yang ditawarkan sehingga memuaskan konsumen. (Maspufah, 2020)

3. Promosi Pemasaran (Promotion)

Promosi pemasaran merupakan sarana komunikasi yang digunakan untuk menginformasikan, membujuk atau mengingatkan konsumen tentang produk, citra, ide. Manfaat promosi pemasaran diantaranya adalah memberikan informasi, modifikasi tingkah laku, membujuk, dan mengingatkan. (Tjiptono, 2014) dalam (Maspufah, 2020)

4. Saluran Pemasaran/lokasi (Place)

Saluran distribusi menentukan keterjangkauan lokasi oleh konsumen yang terlibat dalam proses pemindahan dan pertukaran produk yang dihasilkan untuk kepentingan, pemuasan keinginan konsumen. (Tjiptono, 2014) dalam (Maspufah, 2020)

5. People (Personil Traits)

People atau Personal Traits merupakan unsur bauran pemasaran (marketing mix), Keberadaan mereka dan hubungan harmonis yang terjalin diantara mereka merupakan salah satu pengaruh bagi konsumen. (Tjiptono, 2014) dalam (Maspufah, 2020)

6. Proses (Process)

Proses tersebut meliputi mekanisme pelayanan, sistem- sistem, prosedur, jadwal kegiatan serta rutinitas penyampaian produk atau jasa kepada konsumen. (Tjiptono, 2014) dalam (Maspufah, 2020) 


\section{Bukti Fisik (Physical Evidence)}

Physical Evidence atau bukti fisik merupakan tempat dimana adanya sebuah interaksi antara perusahaan dengan konsumennya. Sebuah physical evidence mempengaruhi persepsi konsumen akan produk yang ditawarkan (Tjiptono, 2014) dalam (Maspufah, 2020). Physical evidence dibedakan menjadi dua jenis diantanya essential evidence berupa sarana phisik seperti gedung, peralatan kantor dan lainlain selanjutnya peripheral evidence berupa bagian dari sarana phisik yang dapat dimiliki oleh pemakai jasa, misalnya buku pedoman, sertifikat, ijazah.

8. Layanan Pelanggan (Customer Service)

Outcome layanan pelanggan pada pemasaran jasa terlihat pada kegiatan distribusi dan logistic. Sebuah pelayanan memberikan kepuasan konsumen. Kualitas jasa dipersepsikan pada pemikiran pelanggan. (Maspufah, 2020)

\section{METODE PENELITIAN}

Penelitian ini menggunakan pendekatan penelitian kualitatif dengan metode penelitian berdasarakan deskriptif literatur reviewdari teori marketing mix produk jasa dengan pendekatan pada delapan indikator diantaranya pengelolaan product, price, promotion, place, people, process, physical evidence, customer service dan berdasarkan beberapa hasil penelitian terkait dengan penerapan marketing mix pada perguruan tinggi.

Penelitian kualitatif dapat mengangkat masalah yang diteliti dan membutuhkan studi penelitian yang bersifat deskriptif, intensif, menyeluruh, terperinci, serta menghasilkan analisis yang mendalam. (Solihat, Hakim, Rahmayani, \& Trijumansyah, 2021)

\section{HASIL DAN PEMBAHASAN}

\section{Karakteristik Perguruan Tinggi}

Indrajit R.Eko dan R. R.Djokopranoto (2006) (Sihite, 2016) bahwa Pendidikan tinggi adalah pendidikan pada jalur pendidikan sekolah pada jenjang yang lebih tinggi dari pada jenjang pendidikan menengah di jalur pendidikan sekolah. Sedangkan Perguruan tinggi merupakan satuan pendidikan yang menyelenggarakan pendidikan tinggi.

Pendidikan tinggi terdiri atas pendidikan akademik dan pendidikan profesional. Pendidikan akademik merupakan pendidikan yang diarahkan terutama pada penguasaan ilmu pengetahuan, sedangkan pendidikan profesional ialah pendidikan yang diarahkan terutama di kesiapan penerapan keahlian. Pendidikan akademik meliputi : Program Sarjana (S-1) dan Program Pascasarjana yang terdiri dari : Program Magister (S2) dan Program Doktor (S-3), sedangkan Pendidikan profesional meliputi : Program Diploma-1, Diploma-2, Diploma-3, dan Diploma-4. (Sihite, 2016)

\section{Standar Kualitas Perguruan Tinggi Di Indonesia Menurut Kemenristekdikti}

Kemenristekdikti memiliki kewenangan untuk penyelenggaraan pendidikan tinggi, termasuk didalamnya berbagai institusi perguruan tinggi yang ada di Indonesia. Oleh karena itu, kementerian ini dapat menetapkan standar kualitas pendidikan tinggi dalam negeri. Saat ini, komponen penilaian pendidikan tinggi Kemenristekdikti ada lima. Diantaranya sebagai berikut:

1) Kualitas Sumber Daya Manusia, yang mencakup rasio mahasiswa dan dosen, persentase lektor kepala dan guru besar, serta jumlah dosen dengan pendidikan S-3. 
2) Kualitas kelembagaan dimana hal yang menjadi penentu terdiri dari akreditasi jurusan/ program studi dan kelembagaan, jumlah jurusan/ program studi yang terakreditasi internasional, jumlah kerjasama perguruan tinggi, dan jumlah mahasiswa asing.

3) Penilaian Kemenristekdikti yang menitikberatkan pada kegiatan kemahasiswaan, lebih tepatnya seberapa baik kinerja unit kegiatan kemahasiswaannya.

4) Kualitas penelitian dan pengabdian pada masyarakat, dimana memiliki cakupan yang lebih luas yaitu jumlah artikel ilmiah terindeks scopus per jumlah dosen, kinerja pengabdian pada masyarakat, dan kinerja penelitian.

5) Kualitas inovasi, yang mengacu pada kinerja inovasi perguruan tinggi bersangkutan. (https://pddikti.kemdikbud.go.id/)

Menurut Kemenristekdikti (https://pddikti.kemdikbud.go.id/) Perguruan tinggi dilakukan pemeringkatan dimana indikator penilaian pemeringkatan perguruan tinggi tahun 2019 berfokus pada indikator atau penilaian yang berbasis Output - Outcome Base dengan tujuan agar nantinya dapat membuat kebijakan yang ada di masing-masing perguruan tinggi untuk mewujudkan perguruan tinggi yang berkualitas. Adapun indikator berbasis Output - Outcome Base tersebut diantaranya :

1) Kinerja input sebesar 15\%: dosen pendidikan S3, dosen guru besar/lektor kepala, rasio jumlah mahasiswa dan dosen, jumlah mahasiswa asing, dan jumlah dosen asing

2) Proses sebesar 25\%: akreditasi perguruan tinggi dan prodi, pembelajaran daring, kerja sama universitas, kelengkapan laporan dan laporan keuangan.

3) Kinerja output sebesar 25\%: jumlah artikel ilmiah terindeks per dosen, kinerja penelitian dan mahasiswa serta jumlah prodi terakreditasi internasional

4) Outcome sebesar 35\%: kinerja inovasi, jumlah mahasiswa diterima bekerja dalam 6 bulan, jumlah sitasi per dosen, jumlah paten per dosen, dan kinerja pengabdian masyarakat.

\section{Penerapan Marketing Mix Pada Perguruan Tinggi}

Perguruan tinggi di Indonesia berjumlah 4.621 yang terbagi pada perguruan tinggi negeri sebanyak 122 dan perguruan tinggi swasta berjumlah 3.129 yang terbagi pada jenjang universitas, institute, sekolah tinggi, akademi, akademi komunitas, dan politeknik. Berdasarkan angka tersebut tentunya jumlah perguruan tinggi swasta lebih banyak dibanding dengan perguruan tinggi negeri, hal ini tentunya dalam mengembangkan perguruan tinggi swasta diperlukan sebuah strategi marketing mix sebagai langkah untuk meningkatkan jumlah calon mahasiswa.

Beberapa penelitian yang telah dilakukan oleh Maspulah dalam hasil penelitiannya menyampaikan bahwa pengujian tersebut dilakukan pada tujuh variabel Marketing Mix yang terdiri dari Produk, Harga, Promosi, Lokasi, Personil, dan Proses. Bukti Fisik berpengaruh secara signifikan terhadap keputusan mahasiswa studi lanjut di STIE Mandala Jember, sedangkan variabel X5 (Personil) dan variabel X6 (Proses) tidak berpengaruh secara signifikan terhadap keputusan mahasiswa studi lanjut di STIE Mandala Jember. Variabel yang berpengaruh paling dominan dari hasil penelitian adalah variabel promosi.(Maspufah, 2020), hal ini juga sesuai dengan penelitian yang dilakukan oleh Karuniawati yang menyampaikan bahwa langkah-langkah perencanaan marketing mix adalah penentuan kebutuhan dan keinginan pelanggan, memilih pasar sasaran khusus 
(special target market), menempatkan strategi pemasaran dalam persaingan, pemilihan strategipemasaran. Dalam strategi marketing mix terdapat 4P pemasaran yang perludiperhatikan yaitu: product (produk), price (harga), place (tempat), dan promotion(promosi).(Karuniawati, n.d.). Namun dari hasil penelitian lainnya yang dilaksanakan oleh Rahman menunjukan bahwa dimensi Produk, Harga, dan Promosi memiliki pengaruh yang signifikan terhadap Minat Kuliah di STIE Dahani Dahanai, sementara itu dimensi Distribusi tidak memiliki pengaruh yang signifikan. Dimensi Produk memiliki pengaruh paling signifikan terhadap minat kuliah disebabkan terkait Program Studi yang ditawarkan oleh STIE Dahani Dahanai yaitu Program Studi Manajemen yang paling banyak diminati oleh para Mahasiswa.(Rahman, 2021)

Berdasarkan dari hasil penelitian diatas, akan dilakukan sebuah penerapan marketing mix sesuai dengan Tjiptono (2014) dimana marketing mix atau bauran pemasaran jasa terdiri dari delapan variabel yaitu:

\section{Produk(Product)}

Dalam jasa Perguruan Tinggi, produk yang ditawarkan kepada calon mahasiswa (pasar) adalah reputasi, prospek, layanan pendidikan (Tri Darma perguruan tinggi), variasi pilihan program studi dan variasi Fakultas. Perguruan tinggi yang mampu memenangkan persaingan dengan perguruan tinggi lain adalah perguruan tinggi yang dapat menawarkan reputasi dan mutu pendidikan yang baik, prospek yang cerah bagi mahasiswa setelah lulus dari perguruan tinggi tersebut, dan pilihan Program Studi dan Fakultas yang sesuai dengan bakat dan minat mereka. Program studi yang banyak dimasuki dan paling menarik bagi para mahasiswa adalah program studi yang memiliki prospek cepat mendapat pekerjaan. Produk jasa Perguruan Tinggi termasuk kurikulum perguruan tinggi. Perguruan Tinggi yang bagus memiliki kurikulum yang tepat, khusus, luas dan inovatif sesuai dengan KKNI (Kompetensi Kelulusan Nasional Indonesia), yang sesuai dengan perkembangan keilmuan dan sesuai dengankebutuhan pasar kerja. Produk Jasa Perguruan Tinggi lainnya adalah memiliki lembaga penelitian yang kredibel yang telah banyak menghasilkan penelitian termasuk juga produk jasa konsultasi dan jasa pelatihan-pelatihan. Produk jasa perguruan tinggi harus disesuaikan dengan kebutuhan masyarakat khususnya dunia industri dan pemerintahan (birokrasi) sehingga ada saling membutuhkan.(Sihite, 2016)

2. Harga (Price).

Ada beberapa penentu harga yang berhubungan dengan perguruan tinggi, berikut sesuai dengan hasil penelitian yang dilakukan oleh Sihite yang menyampaikan bahwa biaya perkuliahan tersebut diantaranya biaya pembangunan,biaya SKS, biaya laboratorium, biaya ujian, biaya kelengkapan, biaya perpustakaan, biaya internet, dll. Termasuk juga prosedur pembayaran dan syarat cicilan. Ada beberapa fasilitas lainnya yang berhubungan dengan harga / biaya termasuk juga tata cara dan syarat pembayarannya, ada perguruan tinggi yang membuat kemudahan pembayaran uang kuliah dengan membayarsecara cicilan setiap bulan dan ada perguruan tinggi yang memiliki fasilitas pembayaran uang kuliah dapat dibayar melalui transfer dari ATM hal ini dapat menjadi daya tarik suatu perguruan tinggi. (Sihite, 2016). Selain hal tersebut saat ini ada beberapa perguruan tinggi melakukan sistem pembayaran dengan bekerjasama dengan perbankan melalui virtual account dan marketplace.

Dalam strategi price di Perguruan Tinggi Swasta menetapkan biaya bangunan yang berbeda-beda setiap gelombangnya, biasanya gelombang pertama biaya 
bangunan lebih rendah dari periode berikutnya, hal ini juga dapat mempengaruhi daya tarik sistem penetapan harga perguruan tinggi bagi calon mahasiswa baru.

3. Promosi (Promotion)

Menurut Sihite menyampaikan bahwa promosi yang dilakukan perguruan tinggi antara lain : spanduk, brosur, majalah,koran, pameran, publikasi, kunjungan ke sekolah, kegiatan seni, kegiatan olahraga, radio, televisi, dll. Promosi dilakukan secara terrencana, terpadu dan berkesinambungan dengan memperhatikan unsurunsur komunikasi pemasaran(Sihite, 2016)

Di era digital seperti saat ini tentunya perguruan tinggi harus menyesuaikan dengan keadaan dimana era digital semua media promosi juga dilakukan secara digital. Dalam hal ini tentunya perguruan tinggi memanfaatkan sumber daya digital sebagai faktor utama dalam mempromosikan, seperti conton sosial media sebagai media komunikasi yang banyak diminati oleh semua kalangan, terutama sesaui dengan target market perguruan tinggi adalah usia 17-22 tahun untuk jenjang D3 dan S1 tentunya perguruan tinggi harus memanfaatkan sosial media sebagai media utama dalam mempromosikan, salah satunya media instagram, youtube, bahkan tiktok saat ini sangat digemari juga, dengan hal ini maka informasi dari perguruan tinggi akan tersampaikan pada calon mahasiswa baru.

Berdasarkan hasil peneltian yang dilakukan Siti Richmah dan Diah Yuliana menyampaikan bahwa factor Marketing Mix (Product, Place, Promotion, Price) terhadap keputusan masuk STIE Semarang yang dimediasi oleh Word of Mouth. Hanya Product yang tidak berpengaruh positif dan signifikan terhadap keputusanmasuk di STIE Semarang ketika dimoderasi oleh Word of Mouth,sedangkan place, price promotion berpengaruh positif dan signifikan terhadap keputusan masuk di STIE Semarang ketika dimoderasi oleh WOM.(Siti Rochmah, Diah Yuliana, 2017).

4. Saluran Pemasaran/lokasi (Place)

Sesuai dengan hasil penelitian yang disampaikan oleh Sihite, bahwa lokasi jasa perguruan tinggi yang strategis dan mudah dilalui kendaraan umum akanmenjadi daya tarik bagi calon mahasisiwa. Lokasi perguruan tinggi diupayakan menjadi daya tarik calon mahasiswa termasukdari penataan gedung fisik kampus (arsitekturnya). Lokasi perguruan tinggi juga harus dapat dijangkau secara virtual yaitu melalui internet. Berdasarkan situs web, informasi dapat di akses oleh semua pihak dapat diperoleh tanpa harus datang ke lokasi.(Sihite, 2016)

Lokasi bagi perguruan tinggi swasata yang representatif baik lokasi gedung maupun penataan tata letak gedung perkuliahan, tentunya menjadi salah satu faktor daya tarik meningkatkan minat calon mahasiswa baru.

5. People (Personil Traits)

People atau Personal Traits merupakan unsur bauran pemasaran (marketing mix), Keberadaan mereka dan hubungan harmonis yang terjalin diantara mereka merupakan salah satu pengaruh bagi konsumen. (Tjiptono, 2014).

People di perguruan tinggi swasata terdiri dari pengurus yayasan, pimpinan perguruan tinggi mulai dari ketua / rektor, dekan, dan kaprodi, dosen yang memiliki jabatan struktural atau tidak dan seluruh karyawan dalam perguruan tinggi tersebut. Semua people sebagai sumber daya manusia yang harus bekerjasama dalam menjalankan organisasinya dengan baik.

Ada beberapa standar kualitas sumber daya manusia yang ditetapkan oleh Kemenristekdikti dimana pergruan tinggi harus memperhatikan rasio mahasiswa dan 
dosen, persentase jabatang fungsional dosen terutama jumlah lektor kepala dan guru besar harus diperhatikan, hal ini tentunya akan terciptanya kulitas pengajar pada perguruan tinggi. Selain itu kualitas penelitian dan pengabdian pada masyarakat yang dilakukan oleh dosen berpartisipasi dengan mahasiswa tentunya menjadi parameter penilaian perguruan tinggi terutama pada jumlah artikel ilmiah terindeks scopus per jumlah dosen, kinerja pengabdian pada masyarakat hal ini menyangkut pada kinerja penelitian dan pengabdian masyarakat yang dilakukan oleh doses sebagai salah satu sumber daya utama pada perguruan tinggi.

6. Proses (Process)

Dalam perusahaan jasa, process menjadi salah satu faktor penting dalam marketing mix, hal ini dikarenakan konsumen menganggap sistem dan prosedur pemberian jasa tersebut sebagai bagian dari jasa itu sendiri. Proses tersebut meliputi mekanisme pelayanan, sistem-sistem, prosedur, jadwal kegiatan serta rutinitas penyampaian produk atau jasa kepada konsumen.(Tjiptono, 2014).

Pada perguruan tinggi sebuah proses menyangkut pelayanan perkuliahan seperti proses untuk calon mahasiswa baru, proses saat kuliah untuk seluruh mahasiswa dan proses pasca kuliah untuk alumni atau mahasiswa yang telah lulus. Hal tersebut tentunya sebuah proses yang harus diperhatikan oleh semua perguruan tinggi karena berhubungan erat dengan kegiatan mahasiswa.

7. Bukti Fisik (Physical Evidence)

Physical Evidence atau bukti fisik yaitu tempat dimana produk jasa diciptakan dan terdapat interaksi antara penjual dan konsumennya. (Tjiptono, 2014)

Physical evidence pada perguruan tinggi dapat terlihat dari bukti fisik berupa gedung perguruan tinggi. Lingkungan perguruan tinggi yang kondusif tentunya harus memperhatikan sistem kegiatan mengajar yang representatif, seperti ruang belajar yang memiliki fasilitas dan media pembelajaran yang lengkap, ruang perkuliahan, ruang laboratorium, ruang perpustakaan, ruang ekstrakulikuler, ruang interaksi antar mahasiswa (taman atau kantin) atau tempat diskusi dan sosialisasi. Namun seiring dengan perkembangan jaman di era digital dan sejak adanya kasus Covid sejak tahun 2020 dimana diwajibkan untuk belajar online maka perlu juga disediakan ruang khusus untuk menyelenggarakan pembelajaran atau seminar online.

8. Layanan Pelanggan (Customer Service)

Layanan pelanggan dalam pemasaran jasa lebih dilihat sebagai hasil (outcome) dari kegiatan distribusi dan logistik, dimana pelayanan tersebut diberikan kepada konsumen untuk mencapai kepuasan.(Tjiptono, 2014)

Layanan pelanggan di perguruan tinggi merupakan tugas senua pihak baik dalam pra perkuliahan, saat proses perkuliahan maupun layanan pasca perkuliahan, hal ini tentunya sangat berkaitan erat dengan indikator process dalam marketing mix. Menurut Sudhana yang menyampaikan bahwa perguruan tinggi disarankan untuk melakukan usaha-usaha selain marketing mix yang sifatnya konstan, terus menerus misalnya pelatihan, seminar dan open house, dalam upaya menarik minat dan meyakinkan calon konsumen (prospek). Hasil penelitian ini yaitu kualitas pelayanan berpengaruh signifikan terhadap kepuasan dari mahasiswa, bauran pemasaran berpengaruh signifikan terhadap kepuasan dari mahasiswa, kualitas pelayanan tidak berpengaruh signifikan terhadap loyalitas dari mahasiswa, bauran pemasaran berpengaruh signifikan terhadap loyalitas dari mahasiswa dan kepuasan mahasiswa berpengaruh signifikan terhadap loyalitas dari mahasiswa(Sudhana et al., 2019) 
Selain marketing mix tentunya ada beberapa kegiatan yang dilakukan oleh perguruan tinggi dalam menarik perhatian calon mahasiswa hal ini sesuai dengan penelitian yang dilakukan oleh Sudhana yang menyampaikan bahwa perguruan tinggi disarankan untuk melakukan berbagai usaha selain dari marketing mix yang sifatnya konstan, terus menerus seperti mengadakan pelatihan, seminar dan open house, dalam upaya menarik minat dan meyakinkan calon konsumennya (prospek). (Sudhana et al., 2019)

\section{KESIMPULAN}

Adapun hasil penelitian menunjukan bahwa ada delapan indikator dalam marketing mix yang efektif diterapkan pada perguruan tinggi diantaranya pengelolaan product, price, promotion, place, people, process, physical evidence, customer service dan diluar indikator tersebut sebaiknya perguruan tinggi menerapkan berbagai usaha selain marketing mix yang sifatnya konstan, terus menerus misalnya pelatihan, seminar dan open house. Perguruan tinggi juga harus mulai memikirkan bagaimana sebaiknya pembelajaran online yang dapat menghasilkan pembelajaran yang diminati oleh mahasiswa. Karena tidak menutup kemungkinan untuk ke depannya system belajar hybrid menjadi salah satu faktor penentu mahasiswa untuk memilih suatu Perguruan Tinggi. 


\section{REFERENSI}

Hidayati, N. (2021). Peran Marketing Mix 3P (People, Process, Phisycal Evidence) dalam Keputusan Orangtua Memilih Man 2 Kuningan, 6, 20-36.

Karuniawati, C. (n.d.). Strategi Marketing Mix dalam Pemasaran Produk. Jurnal Studi Islam Dan Sosial, 10(1), 43-51. Retrieved from http://repository.fisipuntirta.ac.id/827/1/

Maspufah, H. (2020). Analisis Marketing Mix Terhadap Mahasiswa Baru Dalam Memutuskan Studi Lanjut Pada Sekolah Tinggi Ilmu Ekonomi Mandala Jember. JABE (Journal of Applied Business and Economic), 6(4), 400. https://doi.org/10.30998/jabe.v6i4.5830

Rahman, V. (2021). Evaluasi Penentu Minat Studi Pada Perguruan Tinggi Swasta dengan Perspektif Marketing Mix, 5(2), 71-81. https://doi.org/10.31602/atd.v5i2.4366

Risdwiyanto, A., \& Kurniyati, Y. (2015). Strategi Pemasaran Perguruan Tinggi Swasta di Kabupaten Sleman Yogyakarta Berbasis Rangsangan Pemasaran. Jurnal Maksipreneur: Manajemen, Koperasi, Dan Entrepreneurship, 5(1), 1. https://doi.org/10.30588/jmp.v5i1.142

Sihite, M. (2016). Marketing perguruan tinggi. Majalah Ilmiah Methoda, 6(2), 64-78.

Siti Rochmah, Diah Yuliana, A. A. (2017). PENGARUH FAKTOR-FAKTOR MARKETING MIX (PRODUCT, PLACE, PROMOTION, PRICE) TERHADAP KEPUTUSAN UNTUK MASUK STIE SEMARANG YANG DIMEDIASI WORD OF MOUTH. Jurnal STIE SEMARANG, 9(1), 130.

Solihat, A., Hakim, L., Rahmayani, R., \& Trijumansyah, A. (2021). Strategi Promosi Melalui Public Relations Kebudayaan Mapag Menak, 3(1), 13-18.

Subagiyo, R., \& Adlan, M. A. (2017). Pengaruh Service Quality, Marketing Mix dan Kepuasan Mahasiswa terhadap Customer Loyalty. Jurnal Ekonomi Modernisasi, 13(1), 1. https://doi.org/10.21067/jem.v13i1.1567

Sudhana, P., Lukmandono, L., \& Prabowo, R. (2019). Pengaruh Marketing Mix Terhadap Impulse Buying Dengan Niche Market Sebagai Moderasi Pada Industri Jasa Pendidikan. Industri Inovatif: Jurnal Teknik Industri, 8(1), 38-44. https://doi.org/10.36040/industri.v8i1.673

\section{Sumber Rujukan ;}

https://jabar.bps.go.id/statictable/2018/03/12/293/jumlah-perguruan-tinggiswasta-di-lingkungan-kopertis-wilayah-iv-menurut-kabupaten-kota-se-jawabarat-2017.html

https://sevima.com/cara-mencari-perguruan-tinggi-terbaik-ini-indikator-yangwajib-digunakan/

https://pddikti.kemdikbud.go.id/ 